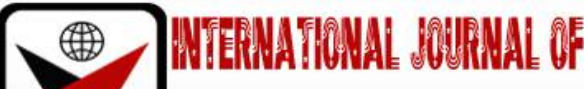

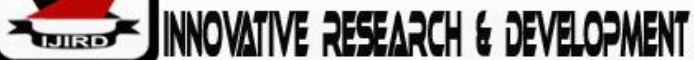

ISSN 2278 - 0211 (Online)

\section{Influence of Higher Institution Attended on Estate Management Graduates' Employment in Ibadan, Nigeria}

\author{
Akinsanya, Ganiyu Moyosolu
}

Lecturer, Department of Estate Management, Federal University of Technology, Nigeria

\begin{abstract}
:
The study examines the preference of Estate Surveying and Valuation firms in Ibadan for higher institutions of learning (HIL) attended by graduates of estate management with a view to determining the influence of HIL on real estate graduate's employment prospect in Southwest Nigeria. Structured questionnaire was administered on the 124 estate firms practicing in the study area and 107 useable questionnaires were duly returned. Descriptive statistics was used for data analysis. The results show the causes of real estate graduates' unemployment in the study area as poor economic policy, estate firms' inability to operate to full capacity, high salary aiming of fresh graduates, dislike for rural practice, high graduates churned out yearly and higher institution attended. Findings also revealed that the estate firms preferred graduates of federal polytechnics to universities and their preference vary among universities. High standard of education, graduate performance, institution reputation, reputable scholars, graduates' skills, and experience were the rationale for the employers 'preference for higher institutions attended by graduates. The study concludes that quality of higher institutions attended has influence on employment prospect of estate management graduate in Ibadan, Southwest Nigeria and recommends that Universities and Polytechnics offering estate management course should endeavor to upgrade their educational standard via curricular review, and provision of adequate teaching and learning facilities.
\end{abstract}

Keywords: Employment, estate management graduates, higher institution attended preference

\section{Introduction}

The role of higher institutions of learning is to impact adequate knowledge and skills on students mainly in preparation for the labour market while the students, parents and the general public expectations alike is that these students upon graduation should be gainfully employed. Unfortunately, in the recent time this lofty expectation is far from being a reality in Nigeria. Although, the rate of graduates' unemployment has become a major global concern among stakeholders, the situation is worst in a developing nation like Nigeria. Unemployment - a situation where young ablebodied people that are willing and seeking to be employed could not find employer neither are able to be self-employed. Currently, hundreds of thousands of graduates are being churned out yearly by Nigerian higher institutions of learning without a correspondent job provision in the labour market. According to the Nigerian Bureau of Statistics (NBS, 2018) the rate of unemployment in Nigeria has increased from 18.8\% in the $3^{\text {rd }}$ Quarter (Q3) of 2017 to 23.1\% in the 3 ${ }^{\text {rd }}$ Quarter (Q3) of 2018. Yet, the number of persons in the labour force (i.e. people who are able and willing to work) increased from 75.94 million in Q3 2015 to 80.6 million in Q3 2016 then to 85.1 million in Q3 2017 and jumped again to 90.5 million in Q3 2018. This is an increase of 14.56 million of labour force within a space of three years. Meanwhile, the total number of people classified by NBS (2018) as unemployed- that is people that were doing nothing at all stood at 17.6 million in $4^{\text {th }}$ Quarter 2017 and increased to 20.9 million in the Q3 2018. The unemployment crisis has probably led some young people in the country into illegal business and activities such as oil bunkering, prostitution, internet fraud, political errand boys among others. The situation is pathetic!

Out of this huge figure lies the Nigerian Estate Management graduates who have nothing to do for livelihood but are grossly dependents. In the past graduates of Estate management were massively employed both in the public and private sectors. At the public level, graduates of estate management are employed as surveyors in Ministry of Works and Housing at Federal and State levels, as valuation officers, Land officers, estate officers etc. At the private level, they are either employed by large multi-national organisation or other companies that have dealings with real estate such as banks, insurance companies, oil gas companies etc. and on the other hand they could be employed by Estate surveying and Valuation firms that happen to be the largest employers of estate management graduates in Nigeria. Alternatively, the graduates could establish their own private practice having fulfilled all necessary requirements. Despite the above opportunities, it is unfortunate to note that several graduates of estate management are still struggling to secure employment while some are enrolling for higher degree in estate management in Nigeria. This seems to be a temporary relief from unemployment perplexity. 
However, several reasons had been adduced as casual factors of unemployment in Nigeria. The high problem has been blamed on inadequate provision for job creation by government, rising demand for higher education, poor economic policy, and dysfunctional and irrelevant skills acquired by graduates from tertiary institutions (Adeyemo, Ogunleye,Oke and Adenle, 2010; Akamu, 2011; Sodipo, 2014; Edinyang, Odey and Gimba, 2015; Egbenta, 2015). Akomolede (2007) noted that the Nigerian Estate Management graduates are 'ill-equipped' for the industry while Oloyede and Adegoke (2007) opined that graduates of estate management were lacking in some knowledge areas Again Adeyemo, Ogunleye, Oke and Adenle, (2010) were of the opinion that graduate personal attributes, institution attended, course of study, class of degree, sex, age, ethnicity, family background, educational level, place of residence, second language, proficiency in English as factors influencing graduate employability. However, a survey on employability factors of business graduates by Abdullah, Kamal and Muna (2014) found that graduate's employability in Kuwait are affected by employers' background characteristics, firms' nature and size, and ownership characteristics (e.g. family, individual, government or corporate). A more recent study (Drydakis, 2016) in UK has also revealed that graduates who studied in universities that are better ranked received more invitations for interviews and higher entry level annual salaries than graduates of universities of lower ranked position. This is an indication that university reputation has influence on employment prospect of graduates. It is against this backdrop that the current study sought the view of the estate surveying and valuation firms in Ibadan, Nigeria on the causes of estate management graduate's unemployment, and whether they have preference for graduates based on the institution attended during selection and recruitment, and the rationale behind their preference. The study therefore aimed at examining the influence of high institution of learning attended on graduates of estate management employability with a view to providing information that could aid student seeking admission to study estate management when making decision to select higher institutions and to motivate higher institutions to embrace and maintain academic standard that meet labour market demand.

\section{Literature Review}

It has been observed that students who attended reputable institutions of learnings received higher earnings than those who attended higher institutions of low reputation (Brunello and Cappellari, 2005; Black and Smith 2006; Canaan and Mouganie 2015; Drydakis 2016; MacLeaod, Riehl, Saavedra and Urquiola, 2017; Witteveen and Attewell 2017). College selection is therefore a crucial investment decision made by most students and parents when sending their children or ward to institutions of higher learning (Rothwell and Kulkarni, 2015; Dale and Krueger, 2012).

However, literatures on effect of college quality on graduates' earnings and employment prospect have shown a degree of inconsistence in outcomes. While some of the studies report a substantial effect of attending quality higher institutions of learning on earnings and employment prospect, some found the effect so minimal, and in some others, there is none at all. The study of Chevalier and Conlon (2003) which was based on three cohorts of UK graduates did not show that students' academic ability is due to quality of higher institution attended and neither is there evidence that university quality affects wage increase. Brunello and Cappellari (2005) examined labour market effect of Alma matter in Italy. The study revealed that university attended had influence on employment prospect of graduates though, not so significant to cause a mobility flow of graduate from underperforming universities to the better ones. Also, Dale and Krueger (2012) estimate the effect of college selectivity college choice of students in 1978 and their self-reported earnings in 1995 It was reported that students that attended quality colleges had similar earnings as students who attended fewer quality colleges but had comparable academic ability.

The Earlier work of Card and Krueger (1992) observed a higher rate of return for graduates of sound educated teachers which are predominantly female. Black and Smith (2006) were of the view that extant literatures underestimate the effect of college quality on graduate wages. Hoektra (2009) investigated the effect of attending leading state universities on the wages of graduates between the age of 28 and 33 years old in the US and showed that for white men, attending the best selective universities causes earnings to be approximately $20 \%$ higher. Hussain, I., McNally, S., Telhaj, S. (2009) examined the relations between various measures of university quality and graduate earnings in the United Kingdom. The study suggests a positive return to attending a higher quality institution for most of the indicators with an average earnings disparity of about 6 percent for a one standard deviation rise in university quality. In 2012, Dale and Krueger adjusted for unobserved student ability by controlling for the average SAT score of the selected colleges the students enrolled for. The study made use of college and beyond (C\&B) survey which was linked to detailed earnings records from the Social Security Administration (SSA). Findings however show that effect of college characteristics are large for black Hispanic students, and from students who came from less educated families. Ciriaci and Muscio (2014) investigated the influence of university quality and their research performance on employability of 47,342 graduates in all science disciplines in Italy. Econometric approach was adopted and the research outcome indicated an increased probability of getting job by graduates who finished from universities with good research performance. Canaan and Mouganie (2015) used a regression discontinuity design to determine the relationship between quality of higher education and earning outcomes of students who marginally passed and those that failed the first round of the French Baccalaureate examination. They noticed an increase admission to quality higher institutions of learning led to a significant earning premium. Drydakis (2016) studied the effect of University attended on graduates' labour market prospect in the UK. The study compared employment prospect of Bachelor of Science graduates in Economic from different universities but have the same set of entry standards. The results indicate that graduates who studied in universities that are better ranked, based on UK league tables, received more invitations for interviews and higher entry level annual salaries than graduates of universities of lower ranked position. MacLeaod, Riehl, Saavedra and Urquiola (2017) explore the effect of college reputation on labour market outcomes using Administrative data and a natural experiment from Colombia. The study 
revealed that college reputation has positive correlation with graduates' wages progress. Witteveen, D. and Attewell, P. (2017) also established striking differences in earnings which are attributable to college selectivity.

While most of these studies have shown effects of quality universities and colleges on graduate's earnings using administrative data, such data on graduates' destinations and earnings are not readily available if at all exist in this clime. Although, several factors have been identified as probable causes of graduate unemployment, the present study sought to know if higher institutions attended could affect real estate graduate employment in Nigeria.

\section{Methodoldy}

The study examines the influence of higher institution attended on Estate Management graduates' employability in Ibadan the capital of Oyo state, Nigeria. Census sampling techniques was adopted in data gathering from the 124 Estate Surveying and Valuation firms through a well-structured questionnaire. Weighted Mean Score was used rate factors against a predefined scale which assists in assessing the significance of each factor as well as the rankings. The factors are ranked from $1^{\text {st }}$ to the last position in descending order of their weighted mean score. There are many employers of estate management graduates as well in Nigeria both in public and private sectors such as Banking Sectors, Telecommunication Sectors, Manufacturing Industries, Engineering Sectors, Transportation Sectors, Health Sectors, Building Construction, Government Ministries and Estate Surveyors and Valuers Firms. However, the scope will be limited to the Registered Practicing Estate Surveyors and Valuers in Ibadan. The estate firms happen to be the major employers of estate management graduates in Nigeria. Also, only the Eighteen (18) accredited universities and Twenty-three (23) accredited polytechnics offering Estate Management as a course in Nigeria as at 2017 according to the Nigerian Institution of Estate Surveyors and Valuers (NIESV) were considered for the study.

\section{Data Analysis and Presentation of Results}

The section presents and analyze the data collected from the field survey through the use of structured questionnaires administered on the registered practicing Estate Surveying and Valuation firms in. Ibadan, Oyo state Nigeria. Out of 124 questionnaires administered 113 questionnaires were retrieved and only 107 (86.3\%) that were found usable for analysis.

\begin{tabular}{|l|l|l|}
\hline Highest Academic Qualification & Frequency & Percentage \\
\hline HND & 46 & 43 \\
BSc/BTech & 24 & 22 \\
PGD & 8 & 8 \\
MSc/MTech & 29 & 27 \\
PhD & 0 & 0 \\
Total & 107 & 100 \\
\hline Years of experience of the respondents & \\
\hline $1-5$ years & 23 & 21 \\
6-10 years & 37 & 35 \\
$11-15 y e a r s$ & 32 & 30 \\
$16-20$ years & 12 & 11 \\
21 and above & 3 & 3 \\
Total & 107 & 100 \\
\hline Status of the respondents in the firm & 7 & 6.5 \\
\hline Estate Officer & 43 & 40 \\
Estate Surveyors & 23 & 21.5 \\
Manager & 34 & 32 \\
Principal Partner & 107 & 100 \\
Total &
\end{tabular}

Table 1: Respondents Profile (Estate Surveyors \& Valuers Firm)

Source: Field Survey (2017)

The table 1 above reveals the profile of the respondents at the Estate Surveying and Valuation firms in terms of academic qualification, years of experience and their professional status in the firms. The study shows that $43 \%$ of the respondents were HND holders, 22\% were BSc/BTech holders, 8\% were PGD, and 27\% have MSc/MTech while nobody had a PhD degree. As regards the years of experience, $21 \%$ of the respondents have 1-5 years of surveying and valuation experience, $35 \%$ had 6-10 years' experience, $30 \%$ had $11-15$ years of experience, $11 \%$ had $16-20$ years of experience while only $3 \%$ have above 20 years of experience in the profession.

The above analysis indicates that majority of the respondents (43\%) were polytechnics graduates and both the polytechnic and university graduates have had more than five years' experience and had attained the status of associate member as estate surveyors and valuer. The information supplied by the respondents can be relied upon on account of academic qualification and years of experience and professional status. 


\begin{tabular}{|c|c|c|}
\hline $\begin{array}{c}\text { Years of Establishment of } \\
\text { Firm }\end{array}$ & Frequency & Percentage \\
\hline Less than 5 years & 10 & 9 \\
\hline $6-10$ years & 20 & 19 \\
\hline $11-15$ years & 33 & 31 \\
\hline $16-20$ years & 14 & 13 \\
\hline Above 20 years & 30 & 28 \\
\hline Total & 107 & 100 \\
\hline \multicolumn{3}{|l|}{ Branch offices of firm } \\
\hline Having branch offices & 71 & 66 \\
\hline No branch offices & 36 & 34 \\
\hline Total & 107 & 100 \\
\hline \multicolumn{3}{|c|}{ Number of staffs (workers) in the firm } \\
\hline $1-5$ staffs & 27 & 25 \\
\hline $6-10$ staffs & 57 & 53 \\
\hline $11-15$ staffs & 7 & 7 \\
\hline $16-20$ staffs & 13 & 12 \\
\hline Above 20 staffs & 3 & 3 \\
\hline Total & & 100 \\
\hline & 107 & \\
\hline \multicolumn{3}{|c|}{ School attended by staffs (workers) in the firms } \\
\hline Universities graduates staffs & 266 & 35 \\
\hline Polytechnics graduates staffs & 503 & 65 \\
\hline Total & 769 & 100 \\
\hline
\end{tabular}

Table 2: Profile of Estate Surveyors \& Valuers Firm Source: Field Survey (2017)

Table 2 above shows the profile of the firms of Estate Surveying and Valuation sampled. It indicates that only $9 \%$ of the Estate firms were in operation for less than 5 years and another 19\% were established between 6 and 10 years as at the time of the survey. Also, the majority, totaling (72\%) had been in existence for more than 10 years. The table also reveals that $66 \%$ of the firms had branch offices while $34 \%$ did not have any branch beside their present location. The study further investigated the staff capacity of the firms and found that majority (53\%) employed between 6 and 10 graduate staff while another 25\% employed between 1 and 5 staff. Only few firms had staff capacity of above 10 employees as revealed in the table above. Lastly, the types of institution attended by staff members of those firms were investigated as shown in the same table. While $65 \%$ of the staff of the firms graduated from polytechnics, the rest $35 \%$ hold university degree. From the analysis of this table, it could be concluded that though majority of the Estate firms in Ibadan had been established for more than 10 years and had staff capacity of between 6 and 10 members, they primarily employ graduates of polytechnics.

\begin{tabular}{llcc|}
\hline \multicolumn{1}{|c}{ CAUSES } & \multicolumn{2}{c|}{ Estate Surveyors \&Valuers } \\
\cline { 2 - 3 } S/N & Mean & Rank \\
\hline & & \\
1. Poor public policy and economy & 4.34 & $1^{\text {st }}$ \\
2. Estate Management Firms are not fully operating & 4.21 & $2^{\text {nd }}$ \\
3. Fresh graduates aim at receiving high salary & 4.10 & $3^{\text {rd }}$ \\
4. Most graduates don't want to practice in rural areas & 4.10 & $3^{\text {rd }}$ \\
5. Population and high number of graduates & 3.91 & $5^{\text {th }}$ \\
6. Higher institution attended affects graduate's employment & 3.07 & $6^{\text {th }}$ \\
7. Inadequate practical exposure & 2.71 & $7^{\text {th }}$ \\
8. Wide gap between academic and industries & 2.71 & $7^{\text {th }}$ \\
9. Lack of basic knowledge & 2.26 & $9^{\text {th }}$ \\
10. Lack of basic Estate Management Skills & 2.20 & $10^{\text {th }}$ \\
11. Higher institutions not producing employable graduates & 2.13 & $11^{\text {th }}$ \\
12. Age of the graduates & 2.09 & $12^{\text {th }}$ \\
13. Graduates gender (Sex) & 1.79 & $13^{\text {th }}$ \\
\hline
\end{tabular}

Table 3: Causes of Estate Management Graduates' Unemployment Source: Field survey (2017)

The study also sought the perspective of the Estate Surveyors and Valuers to know the causes of Estate Management graduates' unemployment in Nigeria. As seen in table 3above, the Estate Surveyors and Valuers believed that poor public policy, inadequacy of estate firms to full operate to capacity, fresh graduates aiming at receiving high salary 
couple with their unwillingness to practice in rural areas, population and high number of graduates yearly, and higher institution attended affect graduates employment with the mean score ranking of 4.34, 4.21, 4.10, 4.10, 3.91, and 3.07 respectively. However, graduates' gender (1.79), age (2.09), lack of skills (2.20), lack of knowledge (2.26) and inadequate practical exposure (2.71) were found to be least causes of estate management graduates' unemployment in Nigeria. Influence of tertiary institutions attended on Estate Management Graduates employment. Analysis in tables 4, 5 and 6 show the preference of the estate surveying and valuation firms in Ibadan for graduates of public and private universities and polytechnics in Nigeria.

\begin{tabular}{|lcc|}
\hline \multirow{2}{*}{$\mathbf{S} / \mathbf{N} \quad$ Type of higher institution preferred } & \multicolumn{2}{c|}{ Estate Surveyors \&Valuers } \\
\cline { 2 - 4 } & \multicolumn{1}{c}{ Mean } & Rank \\
\hline 1. Federal Polytechnics & 4.16 & $1^{\text {st }}$ \\
2. Federal Universities & 3.98 & $2^{\text {nd }}$ \\
3. State Polytechnics & 3.87 & $3^{\text {rd }}$ \\
4. Private Universities & 3.46 & $4^{\text {th }}$ \\
5. State Universities & 2.80 & $5^{\text {th }}$ \\
\hline
\end{tabular}

Table 4: Preferred Tertiary Institutions for Estate Management Graduates Employment Source: Field Survey (2017)

The table 4 above shows the type of higher institutions of learning offering estate management as a course in Nigeria which graduates the estate firms in Ibadan would prefer to employ. The mean score and ranking as shown above indicate that graduate of federal polytechnics (4.16) are mostly preferred, followed by federal universities with mean score of 3.98. Also, the estate firms will prefer graduates from state polytechnics to private universities in the study area. The mean score of 2.80 indicates that graduates from state universities were given less consideration. The preference for graduates of federal polytechnics could be as a result of the fact that the respondents in this study were predominantly polytechnics' graduates, and the fact that they have higher employment in the study. (See table 1 and 2).

\begin{tabular}{|c|c|c|}
\hline \multirow[t]{2}{*}{ S/N $\quad$ Preferred Universities } & \multicolumn{2}{|c|}{ Estate Surveyors \& Valuers } \\
\hline & Mean & Rank \\
\hline 1. Obafemi Awolowo University (OAU) & 3.58 & $1^{\text {st }}$ \\
\hline 2. The Federal University of Technology Akure & 3.36 & $2^{\text {nd }}$ \\
\hline 3. University of Lagos & 3.14 & $3^{\text {rd }}$ \\
\hline $\begin{array}{l}\text { 4. University of Nigeria, Nsukka } \\
\text { 5. Federal University of Technology Minna(FUT Minna) }\end{array}$ & $\begin{array}{l}3.02 \\
2.74\end{array}$ & $\begin{array}{l}4^{\text {th }} \\
5^{\text {th }}\end{array}$ \\
\hline $\begin{array}{l}\text { 6. Covenant University Ota, Ogun state } \\
\text { 7. Kaduna State University }\end{array}$ & $\begin{array}{l}2.71 \\
2.12\end{array}$ & $\begin{array}{l}6^{\text {th }} \\
7^{\text {th }}\end{array}$ \\
\hline 8. NnamdiAzikiwe University Akwa & 2.08 & $8^{\text {th }}$ \\
\hline 9. Abia State University Uturu & 1.82 & $9^{\text {th }}$ \\
\hline 10. Imo State University Oweri & 1.76 & $10^{\text {th }}$ \\
\hline $\begin{array}{l}\text { 11. Abubakar Tafawa Balewa University } \\
\text { 12. Enugu State University of Science/Technology } \\
\text { 13. University of UyoAkwa Ibom }\end{array}$ & $\begin{array}{l}1.75 \\
1.68 \\
1.67\end{array}$ & $\begin{array}{l}11^{\text {th }} \\
12^{\text {th }} \\
13^{\text {th }}\end{array}$ \\
\hline $\begin{array}{l}\text { 14. Bells University Technology, Ota Ogun State } \\
\text { 15. Caritas University Enugu } \\
\text { 16. Rivers State University of Science \& Tech P/H }\end{array}$ & $\begin{array}{l}1.66 \\
1.58 \\
1.52\end{array}$ & $\begin{array}{l}14^{\text {th }} \\
15^{\text {th }} \\
16^{\text {th }}\end{array}$ \\
\hline $\begin{array}{l}\text { 17. Cross River University of Technology } \\
\text { 18. Joseph Ayo Babalola University Osun State }\end{array}$ & $\begin{array}{l}1.47 \\
1.97\end{array}$ & $\begin{array}{l}17^{\text {th }} \\
18^{\text {th }}\end{array}$ \\
\hline
\end{tabular}

Table 5: Estate Surveyors and Valuers Preference for Universities Graduates Source: Field survey (2017) 
Table 5 shows the graduates of universities that estate firm in Ibadan would prefer for employment in Nigeria. The table reveals that most estate surveying and valuation firms in the study area would prefer graduates of estate management from Obafemi Awolowo University as it ranked $1^{\text {st }}$ with the highest mean score of 3.58 while Federal University of Technology Akure was ranked $2^{\text {nd }}$ with a mean score of 3.36. University of Lagos and University of Nigeria Nsukka Enugu State ranked $3^{\text {rd }}$ and $4^{\text {th }}$ with mean score of 3.14 and 3.02 respectively. Though, the firms will have low preference for the other universities, it is noteworthy, that covenant university, a private institution was ranked above other public and private universities in Nigeria except FUT Minna.

\begin{tabular}{|c|c|c|}
\hline \multirow[t]{2}{*}{ Polytechnics } & \multicolumn{2}{|c|}{ Estate Surveyors \&Valuers } \\
\hline & Mean & Rank \\
\hline 1. Yaba College of Technology, Yaba Lagos & 4.09 & $1^{1:}$ \\
\hline 2. The Polytechnic, Ibadan & 4.05 & $2^{\text {nd }}$ \\
\hline 3. Federal Polytechnic, Auchi & 3.51 & $3^{\text {si }}$ \\
\hline 4. Federal Polytechnic, Ilaro, ogun State & 3.34 & 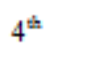 \\
\hline 5. Osun State College of Technology, Esa-Oke & 3.29 & 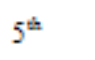 \\
\hline $\begin{array}{l}\text { 6. Lagos State Polytechnic, Ikorodu, Lagos } \\
\text { 7. The Polytechnic, Kaduna }\end{array}$ & $\begin{array}{l}3.22 \\
3.01\end{array}$ & 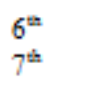 \\
\hline $\begin{array}{l}\text { 8. Federal Polytechnic, Ede, Osun State } \\
\text { 9. MoshoodAbiola Polytechnic, Abeokuta }\end{array}$ & $\begin{array}{l}2.99 \\
2.96\end{array}$ & $\begin{array}{l}8^{=} \\
9^{=}\end{array}$ \\
\hline $\begin{array}{l}\text { 10. Rufus Giwa Polytechnic, Owo Ondo State } \\
\text { 11. Rivers State Polytechnic, Bori } \\
\text { 12. Federal Polytechnic, Bida } \\
\text { 13. Federal Polytechnic, Nkede, Imo state } \\
\text { 14. Kwara State Polytechnic, Ilorin Kwara }\end{array}$ & $\begin{array}{l}2.85 \\
2.73 \\
2.69 \\
2.40 \\
2.31\end{array}$ & 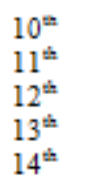 \\
\hline $\begin{array}{l}\text { 15. Akwa Ibom State Polytechnic, } \\
\text { 16. Abia State Polytechnic, Abia State } \\
\text { 17. Federal Polytechnic, Damaturu, Yobe State } \\
\text { 18. Federal Polytechnic, Idah, Kogi State } \\
\text { 19. AkanuIbiam Federal Polytechnic, Ebonyi } \\
\text { 20. Federal Polytechnic, Nasarawa }\end{array}$ & $\begin{array}{l}2.15 \\
2.07 \\
1.87 \\
1.66 \\
1.63 \\
1.58\end{array}$ & 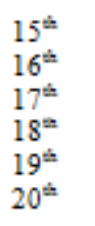 \\
\hline 21. Federal Polytechnic, Oko Anambra State & 1.57 & $21^{1:}$ \\
\hline 22. Federal Polytechnic, Bauchi & 1.55 & $22^{\text {nd }}$ \\
\hline 23. Ken Saro-Wiwa Polytechnic, Bori & 1.54 & $23^{\text {nd }}$ \\
\hline
\end{tabular}

Table 6: Estate Surveyors and Valuers Preference for Polytechnics Graduates Source: Field Survey (2017)

The preference of Estate firms in Ibadan for graduates of accredited Polytechnics they would like to employ is revealed in table 6 above. The table shows that YabaCollege of technology, The Polytechnic, Ibadan, Federal Polytechnic Auchi, Federal Polytechnic Ilaro, Osun State College of Technology, Esa-Oke, Lagos state Polytechnic, Ikorodu, and The Polytechnic Kaduna are the most preferred polytechnics for graduates' employment in the study area. These preferred polytechnics had a mean score of 4.09, 4.05, 3.51, 3.34, 3.29, 3.32, and 3.01 respectively. the mean score of the remaining 16 polytechnics are less that average (3.0) which shows that their graduates are less preferred during graduate selection and recruitment. 


\begin{tabular}{|c|c|c|}
\hline \multirow[t]{2}{*}{ Reasons for Preference } & \multicolumn{2}{|c|}{ Estate Surveyors \&Valuers } \\
\hline & Mean & Rank \\
\hline 1. Education standard in my preferred institution is High & 4.12 & $1^{\text {st }}$ \\
\hline $\begin{array}{l}\text { 2. Graduates of my preferred institution are found } \\
\text { productive irrespective of their class of degree }\end{array}$ & 4.10 & $2^{\text {nd }}$ \\
\hline 3. My preferred institution is reputable (famous) In Nigeria & 4.08 & $3^{\text {rd }}$ \\
\hline $\begin{array}{l}\text { 4. Graduates of my preferred institution are usually } \\
\text { sound academically. }\end{array}$ & 4.02 & $4^{\text {th }}$ \\
\hline $\begin{array}{l}\text { 5. There are reputable scholars of estate management in } \\
\text { those institutions. }\end{array}$ & 3.93 & $5^{\text {th }}$ \\
\hline $\begin{array}{l}\text { 6. Graduates of my preferred institution usually } \\
\text { demonstrate requisite skills }\end{array}$ & 3.82 & $6^{\text {th }}$ \\
\hline $\begin{array}{l}\text { 7. They are better in all practical aspects of estate } \\
\text { surveying and valuation }\end{array}$ & 3.76 & $7^{\text {th }}$ \\
\hline $\begin{array}{l}\text { 8. Duration of their Industrial Training is more than } \\
\text { other institutions } \\
\text { 10. I am an alumnus of the institution }\end{array}$ & $\begin{array}{l}3.54 \\
3.24\end{array}$ & $8^{\text {th }}$ \\
\hline
\end{tabular}

Table 7: Reasons for Preference for Graduates of Some Higher Institution Source: Field Survey (2017)

The study further investigated the rationale behind the preference of the estate firms for graduates of some higher institution of learning in Nigeria. All reasons adduced in the questionnaire were accepted and rated high than average mean as seen in table 7 above. However, education standard (4.12), graduate productivity (4.10), institution reputation (4.08),and academic soundness of graduates (4.02) were the topmost reasons for considering graduates of the preferred higher institution of learning for employment in Nigeria.

\section{Results and Discussion}

Finding reveals that out of 769 graduates of estate management working in estate firms in Ibadan only 266 being $35 \%$ were universities graduates while 503 representing 65\% were from polytechnics (Table 2). This implies that graduates of polytechnics are mostly considered for employment among the estate firms in Ibadan.

Table 3 relates to the causes of estate management graduate's unemployment from the perspectives of Estate Surveying and Valuation firms in Ibadan, Nigeria. Finding shows six major factors which are causing unemployment of estate management graduates to be Poor public economic policy (4.34), inadequacy of estate firms to operate to their full capacity (4.21), high salary aim of fresh graduates (4.10), graduates do not want to practice in rural areas (4.10), high population of graduates (3.91) being churned out yearly and higher institution attended (3.07). However, graduates gender (1.79), age (2.09), lack of skills (2.20), lack of knowledge (2.26) and inadequate practical exposure (2.71) were found to be least causes of estate management graduates unemployment in Nigeria. The finding also shows that, the higher institution attended by graduates of estate management influences their possibility of being employed in the labour market. The preferable university's graduates of estate management by estate firms in Ibadan are; Obafemi Awolowo University (OAU), The Federal University of Technology Akure (FUTA), University of Lagos (UNILAG), and University of Nigeria Nsukka respectively while Covenant University in Ota Ogun State was the main private university preferred by the estate firms. Among the 23- accredited polytechnic offering estate management as a course in Nigeria, the estate firms in Ibadan mostly preferred graduates from Yaba College of Technology(4.09), The Polytechnic Ibadan (4.05), Federal Polytechnic, Auchi(3.51), Federal Polytechnic, Ilaroogun State (3.34),Osun state College of Technology, Esa-Oke (3.29), Lagos State Polytechnic, Ikorodu Lagos (3.22) and The Polytechnic, Kaduna (3.01). None of the above polytechnics are privately owned and they are from South-western Nigeria except Federal Polytechnic, Auchi from the South-South and The Polytechnic Kaduna located at the North West Nigeria. Also, the reasons for preferring estate management graduates of some higher institutions learning by the estate firms in Ibadan were high educational standard of those schools, productiveness of their graduates, institutions reputation in Nigeria, graduates academic soundness, presence of reputable scholars, graduate's demonstration of practical experience and requisite skills. In addition, this category of employers would like to consider graduates from their alma mater.

The findings of the study have implications on higher institutions of learning, aspiring students and graduates of estate management in Nigeria. Firstly, while the mostly preferred universities and polytechnics will be having surplus candidates aspiring to gain admission into those institutions, the less preferred might not have candidates or get less than their capacity. Secondly, most of the students aspiring to study estate management in those preferred higher institutions might struggle for years without admission or probably choose another course. Reduction in the number of students admitted to study estate management will definitely have a long-term negative effect on the Estate surveying and Valuation profession in Nigeria. 
Thirdly, the less preferred institutions of learning might want to scrap the course for wanting of students, and lay off their academic and supportive staff which might further aggravates the unemployment saga in the country. Lastly, graduates of those less preferred institutions may roam for years seeking employment opportunity. The unemployment imbroglio however could further escalate crime rate in the country.

\section{Recommendation}

Based on the findings of this study, it is recommended that Universities and Polytechnics offering estate management course should endeavor to upgrade their educational system via curricular review, and provision of adequate teaching and learning facilities, paying attention to skill acquisition and practical training of their student as this enhances the chances of graduates gaining employment in estate firms. Prospective students should take cognizant of the likely influence of those higher institutions of learning offering estate management course on their own employment opportunity when taking decision to enroll for higher education.

\section{Conclusion}

This study has investigated the influence of higher institution of learning on estate management graduate's employability in Nigeria and made recommendations to enhancing their employment and reducing employers' discrimination against graduates. The study shows that the Estate surveying and Valuation firms in Ibadan had preference for higher institution attended by graduates of Estate Management in Nigeria. Majority of the employees in the Estate firms in the study area were polytechnic graduates and the firms would prefer to employ graduates of federal polytechnics to federal university in Nigeria. Comparatively, high education standard, institution reputation and graduate's demonstration of practical experience and requisite skills endears graduates of the preferred higher institutions of learning to the employers. The study concludes that higher institution attended influence estate management graduate's employment in Ibadan, Nigeria.

\section{Acknowledgment}

Olawale Heziekiah - the research assistance who helped in gathering data for this study is hereby acknowledged

\section{References}

i. Adeyemo, S. A., Ogunleye, A. O., Oke, C. O. and Adenle, S. O. (2010) A survey of factors determining the employability of science and technology graduates of polytechnics and universities in the Nigerian labour market. Journal of Science and Technology Education Research Vol. 1(5), pp. 99 - 106, Available online http://www.academicjournals.org/JSTER

ii. Akanmu, Olu (2011) - Graduate Employment and Employability Challenges in Nigeria - paper presented at British Council Global Higher Education Conference in Hong - $\quad$ Kong $\quad$ in 12 th March, 2011.

iii. Akomolede, K. (2007) “Estate management education and practice in 21 st century" A paper Presented at the continuing professional development and practice (CPD) seminar of the Nigeria institution of estate surveyors and valuer (NIESV) Lagos State branch.

iv. AL-Mutairi, A., Naser, K.\&Saeid, M. (2014) Employability Factors of Business Graduates in Kuwait: Evidence from An Emerging Country. International Journal of Business $\quad$ and $\quad$ Management; $\quad$ Vol. 9, No. 10; 2014.http://dx.doi.org/10.5539/ijbm.v9n10p49.

v. Black, D. A. and Smith, J. A. (2006). Estimating the Returns to College Quality with Multiple Proxies for Quality.Journal of Labor Economics, 24: 701-728

vi. Brunello, G. and Cappellari, L. (2005) The Labour Market Effects of Alma Mater: Evidence from Italy. IZA Discussion Paper No. 1562. Available at http://ssrn.com/abstract=706344

vii. Canaan, S. and Mouganie, P. (2015) Quality of Higher Education and Earnings: Regression Discontinuity Evidence from the French Baccalaureate. Available at http://conference.iza.org/conference_files/SUMS_2015/canaan_s21735.pdf

viii. Card, D. and Krueger, A,B. (1992) Does School Quality Matter? Returns to Education and the Characteristics of Public Schools in the United States.The Journal of Political Economy, Vol. 100, No. 1.(Feb., 1992), pp. 1-40. Availableat::http://links.jstor.org/sici?sici=00223808\%28199202\%29100\%3A1\%3C1\%3ADSQMRT\%3E2.0.CO\% 3B2-U

ix. Chevalier, A. and Conlon, G. (2003) Does it Pay to Attend a Prestigious University? Centre for the Economics of Education (CEE) Discussion Paper P0033.

x. Ciriaci, D. and Muscio, A. (2014) University Choice, Research Quality and Graduates' Employability: evidence from Italian national survey data. European Educational $\quad$ Research Journal Volume 13 Number 2 2014 http://dx.doi.org/10.2304/eerj.2014.13.2.199

xi. Dale, S.B. and Krueger,A.B. (2002)Estimating the Payoff to Attending a More Selective College: An Application of Selection on Observables and Unobservables. The Quarterly Journal of Economics, November p. 1491 - 1527 EBSCO publishing

xii. Dale, S. B. and Krueger, A. B. (2014). Estimating the Effects of College Characteristics over the Career Using Administrative Earnings Data. Journal of Human Resources, 49: 323-358.

http://jhr.uwpress.org/content/49/2/323.full.pdf+html

xiii. Drydakis, N. (2016) Effect of University Attended on Graduates' Labour Market Prospects: A Field Study of Great Britain. Anglia Ruskin University and IZA.Discussion Paper No. 9826 
xiv. Edinyang, S. D., Odey, C. and Gimba, J (2005) Academic Factors And Graduate Global Journal of Human Resource Management Vol.3,

No.5, pp.9-17, September

Employability In Nigeria .

xv. Egbenta, I.R. (2015) Employability Skills among Graduates of Estate Management in Nigeria. Journal of Education and Practice Vol.6, No.31, 2015

xvi. Hoekstra, M. (2009) The Effect of Attending The Flagship State University on Earnings: A Discontinuity-Based Approach. The Review of Economics and Statistics, 91(4): 717- $\quad 724$

xvii. Hussain. I. McNally, S. Shqiponja, T. (2009). University Quality and Graduate Wages in the UK. Institute for the Study of Labour IZA. Discussion Paper Series No. 4043.Bonn: Germany.

xviii. MacLeod, W.B., Riehl. E., Saavedra, J.E. \&Urquiola, M. (2017)The Big Sort: College Reputation and Labour Market Outcomes American Economic Journal: Applied Economics $\quad 2017, \quad 9(3): \quad 223-261$ https://doi.org/10.1257/app.20160126)

xix. NBS (2018) Labour force statistics-volume 1: Unemployment and Underemployment Report.

Q4 $2017-$ Q3 2018. Available at file:///C:/Users/User/Downloads/q4_2017_-_q3_2018_unemployment_report\%20(1).pdf

xx. Oloyede, S... and Adegoke, O.J. (2007) Relevance of Real Estate Education to Practice in Nigeria. Journal of Land Use and Development Studies, Vol 3 N0. 1, pp 50-60

xxi. Chevalier, A. and Conlon, G. (2003)Does It Pay to Attend a Prestigious University? IZA Discussion Paper No. 848

xxii. Sodipo, 0.0. (2014) Employability of Tertiary Education Graduates in Nigeria: Closing The Skills-Gap. Global Journal of Human Resource Management Vol.2, No.3, pp. 28-36,

xxiii. Witteveen, D. and Attewell, P. (2017) The earnings payoff from attending a selective college. Social Science Research 66 154-169. Elsevier Inc 